\section{Improved Protocol for Using Avian Red Blood Cells as Substrates for the Polymerase Chain Reaction}

BioTechniques 26:1080-1082 (June 1999)

A method for direct polymerase chain reaction (PCR) amplification of DNA from nucleated avian red blood cells was previously reported $(5,6)$. This method requires boiling of the fresh blood cells for $10 \mathrm{~min}$ in $50 \mathrm{mM}$ $\mathrm{NaOH}$ before the DNA amplification. In addition, when PCR was performed on fresh blood cells, the efficiency of DNA amplification was lower, as compared with DNA amplification on cells that were kept frozen at $-20^{\circ} \mathrm{C}$ for a few months. Here, we report a modified method that omits the step of boiling the blood in $50 \mathrm{mM} \mathrm{NaOH}$ and provides a significantly higher efficiency of DNA amplification from both fresh and frozen chicken red blood cells.

The PCR mixture $(100 \mu \mathrm{L})$ contained $0.5 \mu \mathrm{L}$ of blood, $50 \mathrm{mM} \mathrm{KCl}, 10$ $\mathrm{mM}$ Tris- $\mathrm{HCl}, \mathrm{pH} 8.0,15 \mathrm{mM} \mathrm{MgCl}_{2}$, $0.2 \mu \mathrm{M}$ of each dNTP, $100 \mathrm{ng}$ of each primer and $1 \mathrm{U}$ of Taq DNA polymerase. PCR conditions are: (i) 3 rounds of $3 \mathrm{~min}$ at $94^{\circ} \mathrm{C}$ followed by $3 \mathrm{~min}$ at $55^{\circ} \mathrm{C}$; (ii) one incubation step for $5 \mathrm{~min}$ at $94^{\circ} \mathrm{C}$, (iii) addition of $1 \mathrm{U}$ of Taq DNA polymerase and (iv) 35 rounds of $1 \mathrm{~min}$ at $94^{\circ} \mathrm{C}, 1 \mathrm{~min}$ at $59^{\circ} \mathrm{C}$, and $1 \mathrm{~min}$ at $72^{\circ} \mathrm{C}$ followed by a final elongation step of $7 \mathrm{~min}$ at $72^{\circ} \mathrm{C}$. The amplified fragments are separated on a $2 \%$ agarose gel and stained with ethidium bromide.

Figure 1 shows the results of DNA amplification of two alleles of the $C d x A$ homeobox gene that are polymorphic at their BamHI site $(3,4)$. The efficiency of the published method $(5,6)$, in which the blood cells are boiled in $50 \mathrm{mM} \mathrm{NaOH}$ (Figure 1, lanes 1-4) was compared with our modified method, in which the same blood cells are mixed in the reaction mixture and subjected to three rounds of boiling (Figure 1, lanes 5-8). When applied to fresh blood cells, the modified method yielded significantly higher levels of DNA amplification as compared with the published method (Figure 1, compare lanes 5 and 6 to lanes 1 and 2). In addition, DNA amplification performed on frozen blood cells gave higher levels of amplification in the modified method (Figure 1, compare lanes 7 and 8 with lanes 3 and 4). The higher levels of amplification were repeatedly observed in many different blood samples and in the different $C d x A$ genotypes (data not shown).

Heme compound is a strong inhibitor of Taq DNA polymerase $(1,2)$, and both the original and the modified 
A

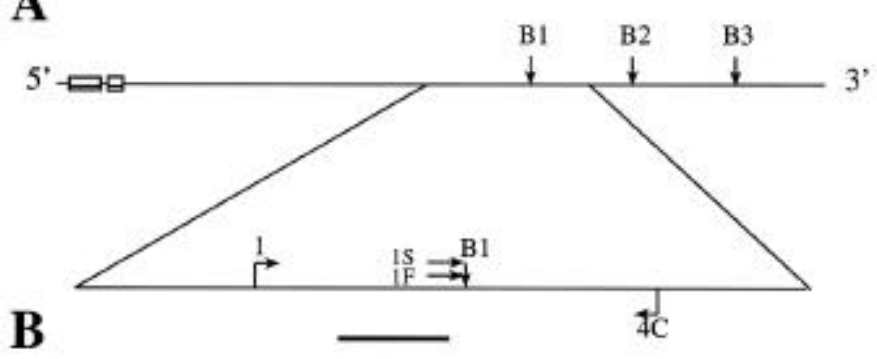

$\begin{array}{lllllllllll}M & 1 & 2 & 3 & 4 & 5 & 6 & 7 & 8 & 9 & 10\end{array}$

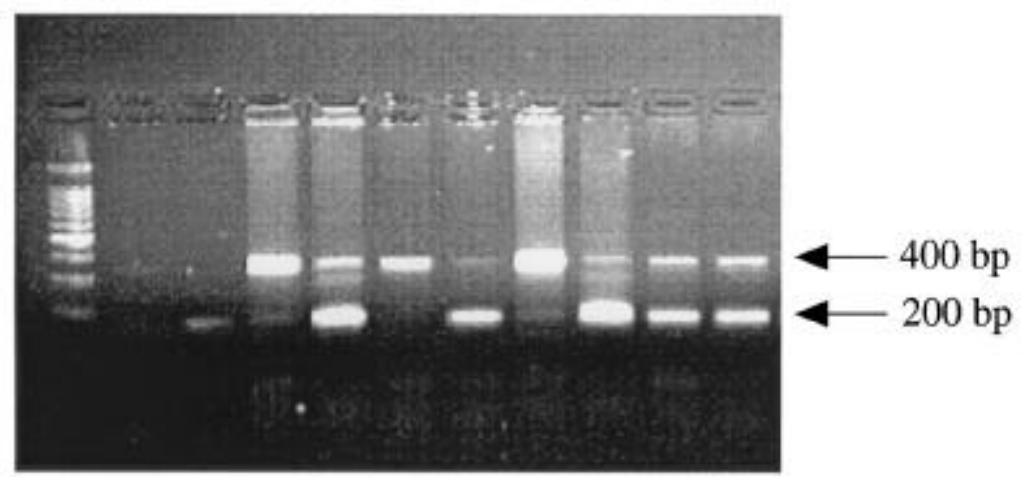

Figure 1. PCR amplification of CdxA alleles from chicken blood cells. (A) The upper map shows the position of the homeobox (striped boxes) and the BamHI sites (B1-B3) in the $C d x A$ gene. The lower map shows an enlargement of the region around the polymorphic site B1 (arrow). The position of the different primers that were used for the amplification is also marked with arrows. Primers 1 (5'-CGCTCCGGTTCGTCACTGCT-3'), 4C (5'-GCTGTCGGCCACCTGTTGTG-3') and 1F (5'-GTGGCACGGACAGGGGATCC-3') were used for the detection of the F allele and primers 1, 4C and 1S (5'-GTGGCACGGACAGGGGATCG-3') were used for the detection of the $S$ allele. Removal of the internal primer (1S or 1F) resulted in a slight increase of amplification (data not shown). The bar below the lower map represents 450 bp for the upper map and $100 \mathrm{bp}$ for the lower map. (B) The PCR products were separated on $2 \%$ agarose gel and stained with ethidium bromide. Each pair of lanes represents PCR amplification of one blood sample (1 and 2, 3 and 4, 5 and 6, 7 and 8) or one DNA sample ( 9 and 10). Samples were amplified either with primers $1,4 \mathrm{C}$ and $1 \mathrm{~F}$ (lanes 1, 3, 5, 7,9) or with primers 1, 4C and 1S (lanes 2, 4, 6, 8, 10). Lanes 1, 2, 5 and 6 show amplification from fresh blood cells; lanes 3, 4, 7 and 8 show amplification from frozen blood cells. Lanes 1-4 show results of amplification according to the previously published technique $(1,2)$; lanes 5-8, amplification according to the method presented here; whereas lanes 9 and 10 are from control amplifications using $50 \mathrm{ng}$ of isolated chicken DNA. Lane M shows size markers of 100-bp ladder.

methods work only with a very limited range of blood-cell concentrations (between $0.125-1.0 \mu \mathrm{L}$ of blood; see References 5 and 6). One difference between the original vs. the modified method is degradation of hemoglobin, or heme compound, by boiling in $\mathrm{NaOH}$ that results in a stronger inhibitory effect on the Taq DNA polymerase $(2,4)$. In addition, it is possible that repeated boiling of the sample before DNA amplification increases the accessibility of the DNA to the primers.

\section{REFERENCES}

1.Akane, A. 1996. Hydrogen peroxide decomposes the heme compound in forensic specimens and improves the efficiency of PCR. BioTechniques 21:392-394.

2.Akane, A., K. Matsubara, H. Nakamura, S. Takahashi and K. Kimura. 1994. Identification of the heme compound co-purified with deoxyribonucleic acid (DNA) from bloodstains, a major inhibitor of polymerase chain reaction (PCR) amplification. J. Forensic Sci. 39:362-372.

3.Iraqi, F., H. Khatib, G. Shani, A. Davarsi, A. Frumkin, G. Zeitlin, M. Soller, A. Fainsod and Y. Gruenbaum. 1992. CHox- cad locus may influence quantitative traits in chicken. J. Exp. Zool. 263:303-308.

4.Khatib, H., D. Bercovich, T. Ratz, Y. Plotzki, A. Fainsod and Y. Gruenbaum. 1995. Mapping the CdxA gene into a new linkage group in chicken. Anim. Genet. 26:211.

5.Khatib, H. and Y. Gruenbaum. 1996. Chicken red blood cells as a substrate for direct polymerase chain reaction. Anim. Genet. 27:53-54.

6.Khatib, H., N. Sagiv and Y. Gruenbaum. 1998. Fresh and Frozen pools of chicken red blood cells as a substrates for direct polymerase chain reaction. Poult. Sci. 77:902-904.

Address correspondence to Prof. Yosef Gruenbaum, Department of Genetics, The Institute of Life Sciences, The Hebrew University of Jerusalem 91904, Israel. Internet: gru@vms.huji.ac.il

Received 17 November 1998; accepted 10 March 1999.

Dani Bercovich ${ }^{1,2}$, Yoram Plotsky $^{1}$ and Yosef Gruenbaum ${ }^{2}$ ${ }^{\prime} M I G A L$-Galilee

Technological Center

Kiryat Shmona

${ }^{2}$ The Hebrew University of

Jerusalem

Jerusalem, Israel

\section{Bridge-Overlap-Extension PCR Method for Con- structing Chimeric Genes}

BioTechniques 26:1082-1086 (June 1999)

Since the discovery of polymerase chain reaction (PCR) (4), innumerable innovations have heralded several important advances in modern molecular biology. One such application is the introduction of predetermined alterations in the sequences of the target genes, for example, site-specific mutations and hybrid gene constructions. In the latter development, chimeric gene constructs are synthesized by an overlap-extension technique, termed splicing by overlap extension (SOE) (1). In this technique, PCR products corresponding to the genes to be spliced are synthesized 